\title{
Implementasi ABSS Accounting Pada Laporan Keuangan CV One Solution Media
}

\author{
Hendra Lesmana ${ }^{1}$, Wati Erawati ${ }^{2}$, Husni Mubarok ${ }^{3}$, Ery Suryanti ${ }^{4}$ \\ 1,2,3,4 Program Studi Sistem Informasi Akuntansi, Universitas Bina Sarana Informatika, Tegal, Jawa Tengah, Indonesia \\ Email: hendra.hla@bsi.ac.id
}

\begin{abstract}
$A B S T R A C T$
Financial reports used in CV. One Solution Media is still done manually, namely making financial reports by recording books on paper or books so that companies often lose proof of transactions and calculations or records that are not in accordance with accounting standards, making the amount of assets, capital or debt in the company not clear, as well as reports the resulting incomplete, there is no balance sheet and changes in the company's capital is also less strict in managing transaction evidence, and requires an accounting information system to create complete, neat, timely presented financial reports and according to accounting standards Cash-based accounting recording systems (Cash Basis), and inventory recording systems using the Perpetual Method. The application used in this research is ABSS Accounting. The research begins with manual and computerized transaction data management, then an analysis is carried out to find a difference. The results of this study indicate that the financial reports generated from manual recording or recording with the ABSS Accounting application are in accordance with accounting standards, but making accounting reports using ABSS Accounting is faster than manual accounting and the risk of experiencing calculation errors is smaller. The purpose of this research is to create quality financial reports for the company, effective, efficient, and in accordance with accounting standards. So that it is beneficial for the company in internal control and support in making decisions.
\end{abstract}

Keywords: Financial Report, Accounting, ABSS Accounting v25, Cash Basis

\begin{abstract}
ABSTRAK
Laporan keuangan yang digunakan pada CV. One Solution Media masih dilakukan secara manual yaitu membuat laporan keuangan dengan mencatat pembukuan di kertas atau buku sehingga perusahaan sering kehilangan bukti transaksi dan perhitungan maupun pencatatan yang belum sesuai standar akuntansi membuat jumlah harta, modal maupun utang yang ada pada perusahaan tidak tampak jelas, serta laporan yang dihasilkan tidak lengkap, tidak ada laporan neraca dan perubahan modal perusahaan ini juga kurang ketat dalam mengelola bukti transaksi, sehingga pencatatan laporan keuangan secara manual dianggap kurang efektif. Sehingga perusahaan membutuhkan sebuah sistem informasi akuntansi untuk menciptakan laporan keuangan yang lengkap, rapi, tersaji tepat waktu, dan sesuai standar akuntansi. Sistem pencatatan akuntansi Berbasis Kas (Cash Basis), dan Sistem pencatatan persediaan menggunakan Metode Perpetual. Aplikasi yang di gunakan dalam penelitian ini yaitu ABSS Accounting. Penelitian diawali dengan pengelolaan data transaksi secara manual dan juga terkomputerisasi, kemudian dilakukan analisis untuk menemukan suatu perbedaan. Hasil dari penelitian ini menunjukkan bahwa laporan keuangan yang dihasilkan dari pencatatan secara manual maupun pencatatan dengan aplikasi ABSS Accounting sesuai dengan standar akuntansi, namun untuk pembuatan laporan akuntansi menggunakan ABSS Accounting lebih cepat jika dibandingkan dengan pencatatan akuntansi secara manual dan resiko mengalami kesalahan perhitungan lebih kecil. Tujuan dari penelitian adalah menciptakan laporan keuangan yang berkualitas bagi perusahaan, efektif, efisien, dan sesuai dengan standar akuntansi. Sehingga bermanfaat bagi perusahaan dalam pengendalian internal serta penunjang dalam pengambilan keputasan.
\end{abstract}

Kata Kunci: Laporan Keuangan, Akuntansi, ABSS Accounting v25, Berbasis Kas

\section{Pendahuluan}

Dalam satu tahun terakhir, beberapa perusahaan telah mulai menggunakan metodologi berbasis aplikasi untuk mengurangi kesalahan, waktu siklus yang berlebihan, proses yang tidak efisien, dan pembengkakan biaya yang terkait dengan sistem pelaporan keuangan [1]. 
Perkembangan ilmu akuntansi dan perkembangan teknologi informasi yang pesat mengakibatkan perubahan signifikan terhadap keduanya [2]. Teknologi saat ini tidak dapat dipisahkan dari jalannya sebuah organisasi karena informasi merupakan salah satu sumber daya yang dapat meningkatkan kompetensi dan strategi untuk membantu visi, misi dan target perusahaan tercapai [3]. Dalam prakteknya sistem informasi di lapangan banyak mengalami masalah, dari sistem informasi yang tidak sesuai kebutuhan atau bisa jadi justru menurunkan kinerja perusahaan. Penggunaan komputer dalam sistem informasi tidak lepas dari penggunaan hardware maupun software, hardware dan software yang memiliki kecepatan dapat menunjang kinerja perusahaan [4].

CV. One Solution Media merupakan perusahaan yang bergerak dalam bidang perdagangan dan jasa barang elektronik. Namun dalam mengelola data keuangan menggunakan masih menggunakan pencatatan manual yang belum sesuai standar akuntansi. Perusahaan tidak ketat dalam mengelola data keuangan sehingga seringkali kehilangan beberapa dokumen transaksi dan menyebabkan jumlah uang di perusahaan dengan jumlah uang dalam catatan keuangan berbeda. Setiap bulan perusahaan hanya membuat laporan laba rugi dan memperkirakan besarnya laba tanpa perhitungan yang akurat karena transaksi kecil tidak tercatat.

Sistem pencatatan laporan keuangan yang digunakan CV. One Solution Media saat ini adalah pencatatan laporan keuangan yang masih dilakukan secara manual, akibatnya perusahaan sering kehilangan bukti transaksi dan perhitungan maupun pencatatan yang belum sesuai standar akuntansi membuat jumlah harta, modal maupun utang yang ada pada perusahaan tidak tampak jelas, serta laporan yang dihasilkan tidak lengkap tidak ada laporan neraca dan perubahan modal. Untuk itu diperlukan sistem informasi berbasis komputer untuk mempermudah dalam laporan keuangan, salah satu solusi yang dapat dilakukan untuk memecahkan masalahan pada CV. One Solution Media yaitu dengan diterapkannya aplikasi ABSS Accounting dalam pembukuan perusahaan. Karena aplikasi ABSS Accounting sesuai dengan standar akuntasi dan jika diterapkan dengan benar tentu dapat menunjang laporan keuangan perusahaan, sehingga perusahaan dapat mengetahui jumlah harta, modal, maupun utang dengan tepat. Laporan keuangan yang dihasilkan lengkap serta penyajiannya lebih mudah, rapi, dan tepat waktu dalam setiap bulannya sesuai dengan tujuan penelitian ini adalah untuk mencari perbedaan pencatatan laporan secara manual dan komputer serta mengimplementasikan sistem informasi akuntansi pada CV. One Solution Media dengan menggunakan perangkat lunak ABSS Accounting agar lebih efisien dalam mengelola transaksi.

Penelitian sebelumnya pada PT. Quntum Electrindo Lestari menggunakan pencatatan laporan keuangan dengan sistem terkomputerisasi atau software akuntansi berupa aplikasi ABSS accounting membuktikan bahwa proses pengolahan data lebih cepat, dikarenakan sistem posting otomatis dan penyusunan laporan otomatis, selain itu software akuntansi lebih efektiv karena perusahaan dapat mereview berkas laporan keuangan setiap saat pada komputer, software akuntansi juga memiliki tingkat ketelitian yang lebih tinggi, software akuntansi akan lebih akurat dalam menjumlahkan hasil sehingga mengurangi kesalahan-kesalahan yang dapat terjadi dalam proses pengolahan data yang dilakukan secara manual. Sehingga dapat disimpulkan dengan penggunaan aplikasi ABSS Accounting dapat mempermudah dalam pengolahan data transaksi keuangan serta dalam penyusunan laporan keuangan yang dibutuhkan perusahaan [5].

\section{Kerangka Teoritis Dan Pengembangan Hipotesis Definisi Akuntansi}

Akuntansi adalah seni pencatatan, pengelompokkan atau pengikhtisaran dan pelaporan yang disajikan dalam laporan keuangan yang berisi sumber-sumber informasi ekonomi yang berguna 
untuk pengambilan keputusan bagi pihak-pihak yang berkepentingan [6]. Menurut Mulyadi akuntansi adalah alat pencatatan dan penyajian data menjadi laporan keuangan yang bertujuan untuk memudahkan mengatur pengelolaan sebuah perusahaan atau lembaga. Jadi dapat disimpulkan bahwa akuntansi adalah merupakan informasi mengenai laporan keuangan pada perusahaan [7].

\section{Sistem Informasi Akuntansi}

Sistem Informasi Akuntansi adalah sebuah sistem yang memproses data dan transaksi guna menghasilkan informasi yang bermafaat untuk merencanakan, mengendalikan, dan mengoperasikan bisnis. Akuntansi sendiri sebenarnya adalah sebuah sistem informasi [8]. Sedangkan menurut Romney sistem informasi akuntansi adalah dalah sistem yang digunakan untuk mengumpulkan, mencatat, menyimpan dan mengelola data untuk menghasilkan suatu informasi [9]. Jadi dapat disimpulkan bahwa sistem informasi akuntansi merupakan sistem yang bermanfaat untuk melakukan transaksi akuntansi.

Sistem Informasi Akuntansi bertujuan untuk:

1. Mengelola dan menyimpan mengenai data transaksi keuangan secara keseluruhan.

2. Data keuangan dapat diproses dan mampu menjadikan informasi dalam pengambilan keputusan manajemen tentang perencanaan dan pengendalian usaha

3. Seluruh aktivitas keuangan perusahaan dapat dipantau.

4. Biaya dan waktu kinerja keuangan menjadi efisien.

5. Dalam periode akuntansi yang diinginkan data keuangan yang sistematis dan akurat dapat tersaji.

\section{Tools Aplikasi}

Aplikasi ABSS Accounting atau yang biasa dikenal dengan sebutan MYOB Accounting. Berikut penjelasan lebih lanjut mengenai aplikasi ABSS Accounting. ABSS ( Asian Business Software Solution) adalah program akuntansi yang sangat dikenal sebelumnya dengan nama MYOB. Sejak Januari 2018, nama MYOB untuk daerah Asia Selatan (South Asia) berubah nama menjadi abss. Adapun tampilan menu, dan perintah-perintahnya tidak mengalami perubahan. abss berkantor pusat di Malaysia [10].

\section{Aplikasi ABSS Accounting v25}

Dalam Website resmi ABSS https://int.abssasia.com menyatakan Same Thing... Different Name MYOB Sount Asia is Now ABSS. Pernyataan tersebut dapat membuktikan bahwa aplikasi MYOB telah berganti nama menjadi aplikasi ABSS.

Di Indonesia untuk skala perusahaan kecil dan menengah yang jumlahnya tak terhitung banyaknya, program yang paling banyak dipakai merupakan program MYOB. Jumlah ini terus bertambah dari waktu ke waktu seiring dengan pesatnya perkembangan bisnis di Indonesia [8]. Aplikasi $M Y O B$ telah digunakan oleh perusahaan di berbagai negara. Di Indonesia perusahaan berskala kecilpun menggunakan aplikasi MYOB dalam menyusun laporan keuangannya, hal ini di karenakan mudah dalam pengoperasiannya, dan memiliki tampilan yang ramah.

Santamour menyatakan bahwa MYOB merupakan program yang sederhana namun lengkap. Untuk ekspansi perusahaan Lombardo telah mensurvei bahwa MYOB salah satu software akuntansi terbaik yang dapat digunakan. Dikarenakan MYOB banyak digunakan di berbagai negara. 
Informasi ini juga ditunjang dengan survei dari Hedtke yang menunjukkan bahwa MYOB merupakan salah satu dari 5 program akuntansi yang banyak digunakan oleh perusahaan level menengah kebawah. Hal ini disebabkan karena faktor kemudahan user friendly, dan pemberian versi trial untuk memberikan kenyamanan bagi konsumen yang akan melakukan uji coba program [11].

\section{Metode Penelitian}

Metode penelitian adalah cara yang digunakan secara sistematis untuk menyelesaikan suatu masalah, metode penelitian yang digunakan dalam menganalisa penelitian ini adalah metode kualitatif descriptive yaitu metode penelitian yang memenfaatkan data kualitatif dan dijabarkan secara deskriptif. Jenis penelitian ini meampilkan hasil data apa adanya tanpa manipulasi atau perlakuan lain [12]. Metode yang digunakan dalam penelitian ini dapat digambarkan sebagai berikut:

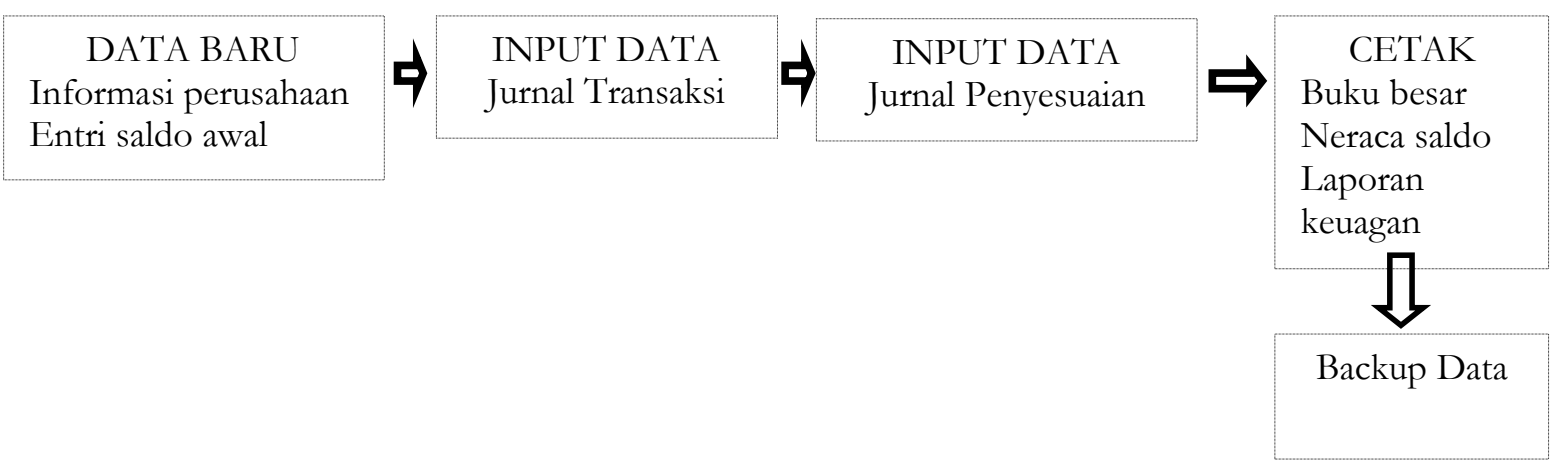

Gambar 1. Metode Penelitian Aplikasi ABSS

Berdasarkan gambar di atas proses penelitian dapat dimulai dengan tahap awal yang dilakukan yaitu megumpulkan dokumen atau bukti bukti transaksi, selanjutnya melakukan pencatatan menggunakan aplikasi $A B S S$ yaitu dari setup awal, kemudian mengisi informasi perusahaan dan input saldo awal setelah itu input data transaksi sampai menghasilkan laporan laba/rugi, laporan perubahan modal, laporan neraca sampai dengan analisis laporan keuangan CV. One Solution Media.

\section{Tempat dan Waktu Penelitian}

Tempat penelitian ini dilakukan di CV. One Solution Media yaitu perusahaan yang bergerak di bidang jasa dan elektronik. Sumber data dalam penelitian ini adalah data kuantitatif yang didapat dari CV. One Solution Media yaitu data transaksi keuangan bulan Februari 2019. Penelitian ini berfokus pada penerapan perangkat lunak dalam menunjang pencatatan laporan keuangan dengan menggunakan aplikasi $M Y O B$ atau yang telah berganti nama menjadi aplikasi $A B S S$.

\section{Teknik Pengumpulan Data}

Teknnik pengumpulan data yaitu cara-cara yang dapat ditempuh untuk memperoleh data yang dibutuhkan [13]. Teknik pengumpulan data yang dilakukan pada penelitian ini adalah:

1. Metode Wawancara

Untuk mendapatkan informasi secara lengkap, maka dilakukan suatu tanya jawab langsung dengan narasumber Ibu Anissa Dila Maryani mengenai kegiatan pengelolaan data keuangan yang biasa dilakukan oleh CV. One Solution Media. 
2. Metode Studi Pustaka

Metode studi pustaka dilakukan melalui literatur-literatur atau referensi-referensi dari media buku, jurnal dan internet. Metode Observasi, Dilakukan sebuah pengamatan terhadap kegiatan yang berlangsung pada CV. One Solution Media. Terutama tentang sistem pencatatan akuntansi yang ada, sehingga diperoleh data-data yang dibutuhkan seperti transaksi dan informasi barang dagangan.

3. Metode Observasi

Observasi merupakan proses sistematis yang mampu merekam pola perilaku aktual orang, benda, serta peristiwa yang terjadi.

\section{Hasil dan Pembahasan}

\section{Hasil Penelitian}

\section{Laporan Keuangan CV. One Solution Media Secara Manual}

Berikut laporan keuangan hasil pengelolaan transaksi CV. One Solution Media secara manual:

\section{Laporan Laba Rugi}

Tabel 1. Laporan Laba Rugi

\section{ONE SOLUTION MEDIA \\ LAPORAN LABA RUGI \\ Periode 28 Februari 2019}

\begin{tabular}{|c|c|c|}
\hline \multicolumn{3}{|l|}{ Pendapatan Penjualan: } \\
\hline Penjualan & & Rp 28.060.000 \\
\hline Pendapatan Jasa & & Rp 3.563 .000 \\
\hline Pendapatan Penjualan Bersih & & Rp 31.623.000 \\
\hline \multicolumn{3}{|l|}{ Harga Pokok Penjualan: } \\
\hline Harga Pokok Penjualan & & $(\underline{\mathrm{Rp} 21.265 .000)}$ \\
\hline Laba Kotor & & $\mathrm{Rp} 10.358 .000$ \\
\hline \multicolumn{3}{|l|}{ Beban Operasi: } \\
\hline Beban Iklan & Rp 281.000 & \\
\hline Beban Telpon dan Listrik & Rp 885.984 & \\
\hline Beban Perlengkapan Toko & $\begin{array}{ll}\mathrm{Rp} & 75.000\end{array}$ & \\
\hline Beban Depresiasi & Rp 807.084 & \\
\hline Beban Sewa & Rp 1.250 .000 & \\
\hline Beban Gaji dan Upah & Rp 4.300.000 & \\
\hline Total Beban Operasi & & ( $\underline{\text { Rp 7.599.068) }}$ \\
\hline Laba Bersih & & $\mathrm{Rp} 2.758 .932$ \\
\hline
\end{tabular}

Sumber: Olah Data (2019)

Tabel di atas merupakan pencatatan laporan laba rugi dari hasil pencatatan secara manual pada transaksi - transaksi di bulan februari 2019. Dimana dari hasil perhitungan di atas menunjukan dana perusahaan mendapatkan laba sebesar Rp. 2.758.932. 


\section{Laporan Perubahan Modal}

Tabel 2. Laporan Perubahan Modal

\section{ONE SOLUTION MEDIA}

LAPORAN PERUBAHAN MODAL

Periode 28 Februari 2019

\begin{tabular}{|l|c|c|}
\hline Modal Iwan Per 1 Februari 2019 & & Rp 209.850.021 \\
\hline Laba Bersih & Rp 2.758.932 & \\
\hline Prive & $(\underline{\operatorname{Rp} 7.500 .000)}$ & \\
\hline & & $\underline{(\mathrm{Rp} \mathrm{4.741.068)}}$ \\
\hline Modal Iwan Per 28 Februari 2019 & & $\mathbf{R p ~ 2 0 5 . 1 0 8 . 9 5 3}$ \\
\hline
\end{tabular}

Sumber: Olah Data (2019)

Tabel 2 merupakan pencatatan laporan perubahan modal dari hasil pencatatan secara manual. Dimana dari hasil perhitungan menunjukan adanya perubahan modal sebesar Rp. 205.108.953.

\section{Laporan Neraca}

Tabel 3. Laporan Neraca

\section{One Solution Media \\ LAPORAN NERACA \\ Periode 28 Februari 2019}

\begin{tabular}{|c|c|c|c|}
\hline \multicolumn{2}{|c|}{ Aktiva } & \multicolumn{2}{|c|}{$\begin{array}{r}\text { Pasiva } \\
\end{array}$} \\
\hline $\begin{array}{l}\text { Aktiva Lancar: } \\
\text { Kas }\end{array}$ & Rp 59.405.537 & $\begin{array}{l}\text { Utang Jangka Pendek: } \\
\text { Utang PPn }\end{array}$ & $(\mathrm{Rp} 649.000)$ \\
\hline Piutang Dagang & $\mathrm{Rp} \quad-$ & & \\
\hline Persediaan Barang Dagang & Rp 47.220.000 & & \\
\hline Perlengkapan Toko & $\mathrm{Rp} \quad 341.500$ & & \\
\hline Sewa Dibayar di Muka & $\underline{\operatorname{Rp~} 5.000 .000}$ & & \\
\hline Total Aktiva Lancar: & Rp 111.967.037 & & \\
\hline Aktiva Tetap: & & Modal: & \\
\hline Peralatan & Rp $\quad 5.700 .000$ & Modal Iwan & Rp 205.108.953 \\
\hline Akum. Peny. Peralatan & $(\mathrm{Rp} \quad 118.750)$ & & \\
\hline Kendaraan & Rp 87.600 .000 & & \\
\hline Akum Peny. Kendaraan & ( $\underline{R p} \quad 688.334)$ & & \\
\hline Total Aktiva Tetap: & Rp 92.492 .916 & & \\
\hline Total Aktiva & Rp 204.459.953 & Total Pasiva & Rp 204.459.953 \\
\hline
\end{tabular}

Sumber: Olah Data (2019)

Tabel di atas merupakan pencatatan laporan neraca per februari 2019 dari hasil pencatatan secara manual. Dimana dari hasil perhitungan di atas menunjukan total aktiva dan pasiva sebesar Rp. 204.459.953. 


\section{Pencatatan Laporan Keuangan dengan Dengan Tools Aplikasi ABSS}

Pada penelirian ini peneliti mengelola data transaksi keuangan CV. One Media Solution selama 1 bulan penuh yaitu bulan Februari 2019. Dalam menerapkan aplikasi ABSS ada beberapa langkah yaitu:

\section{Membuat Database Perusahaan}

Langkah-langkah membuat database perusahaan dapat digambarkan sebagai berikut:

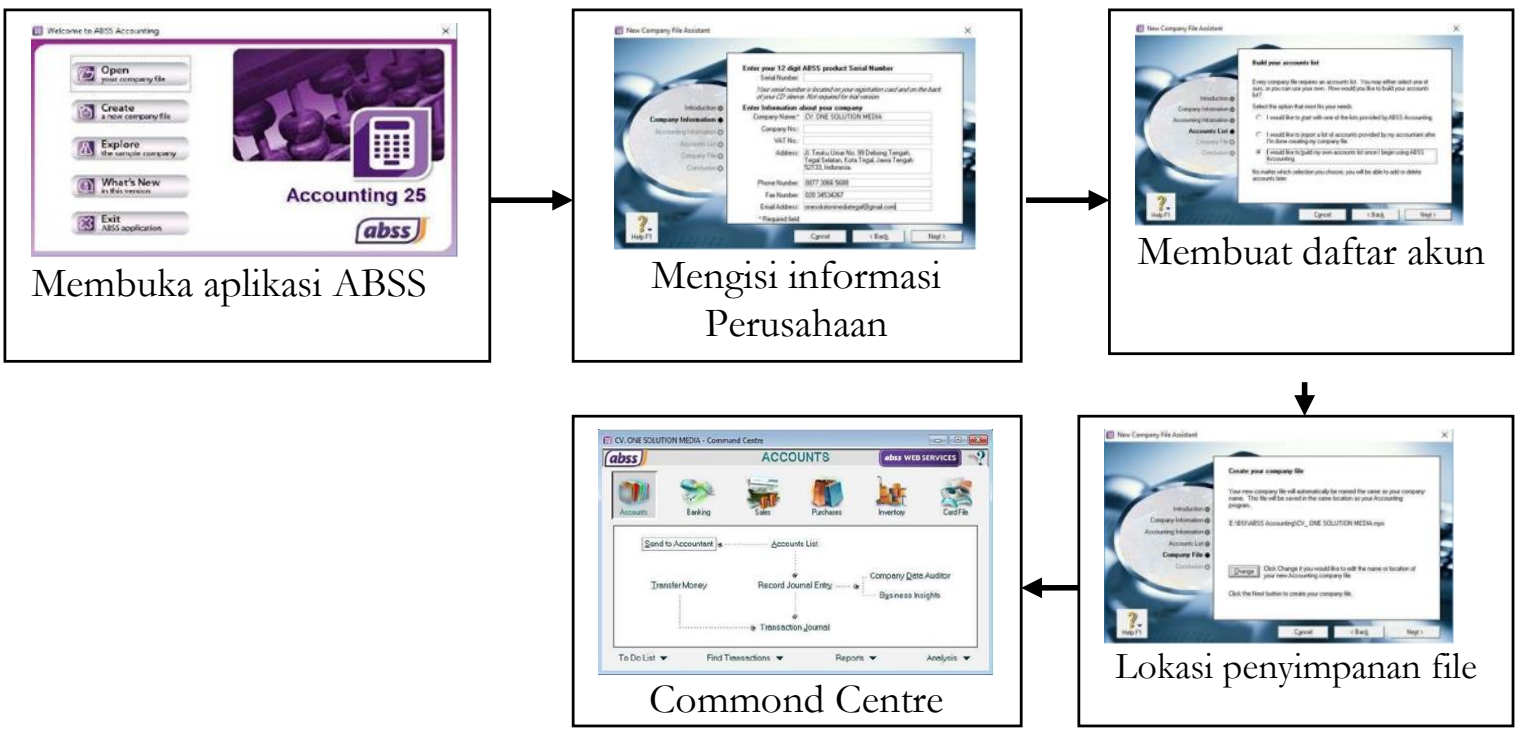

Gambar 2. Pembuatan Database Perusahaan

Proses pembuatan database pada gambar di atas dapat di jelaskan sebagai berikut:

1. Langkah awal membuat database perusahaan adalah membuka halaman awal ABSS Accounting v25.

2. Selanjutnya adalah membuat profil perusahaan dengan Klik Create a new company file, selanjutnya muncul tampilan New Company File Assistant, klik Next, pada tampilan Company Information isi informasi perusahaan, pastikan data perusahaan terisi semua dengan benar.

3. Kemudian pilih menu Account List. Karena akun lebih sedikit dan akan dibuat sendiri maka pilih point ke tiga "I would like to build my own accounts list once I begin using ABSS Accounting" lalu klik Next

4. Selanjutnya muncul jendela berikut. Tentukan lokasi penyimpanan file untuk data perusahaan, lalu klik tombol Change karena akan mengubah lokasi penyimpanan. Kemudian klik Next.

5. ABSS Accounting siap digunakan untuk mengentri dokumen transaksi.

\section{Membuat Link Account}

Sebelum melakukan penginputan data transaksi keuangan, terlebih dahulu menseting beberapa akun yang menjadi penghubunng antara transaksi dengan jurnal, di antaranya adalah Accounts \& Banking Linked Accounts, Sales Linked Accounts dan Purchases Linked Accounts. Langkah-langkah membuat Link. Account adalah sebagai berikut:

\section{Account Banking}

Account Banking digunakan untuk membuat link perkiraan buku besar dan kas/bank. Langkahlangkahnya adalah pilih menu Setup, klik Linked Account, klik Accounts and Banking Accounts.Pastikan 
Bank Account for Undeposited Funds adalah akun Undeposited Funds lalu klik OK. Jika perusahaan menggunakan akun Cash In Bank maka akun Undeposited Funds dapat digantikan dengan Cash In Bank.

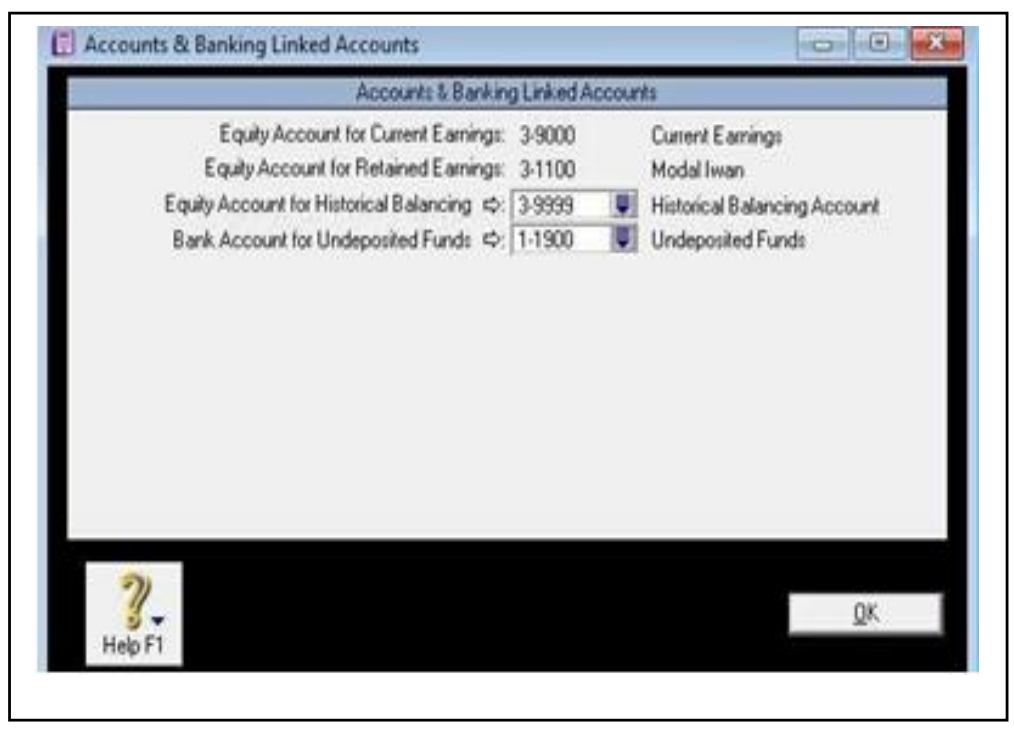

Gambar 3. Bank Linked Account

Selanjutnya Link. Account untuk Sales Accounts digunakan untuk mencatat transaksi penjualan, langkah-langkahnya adalah pilih menu Setup, klik Linked Accounts, klik Sales Accounts. Isi data seperti gambar di bawah ini. Lalu klik $O K$.

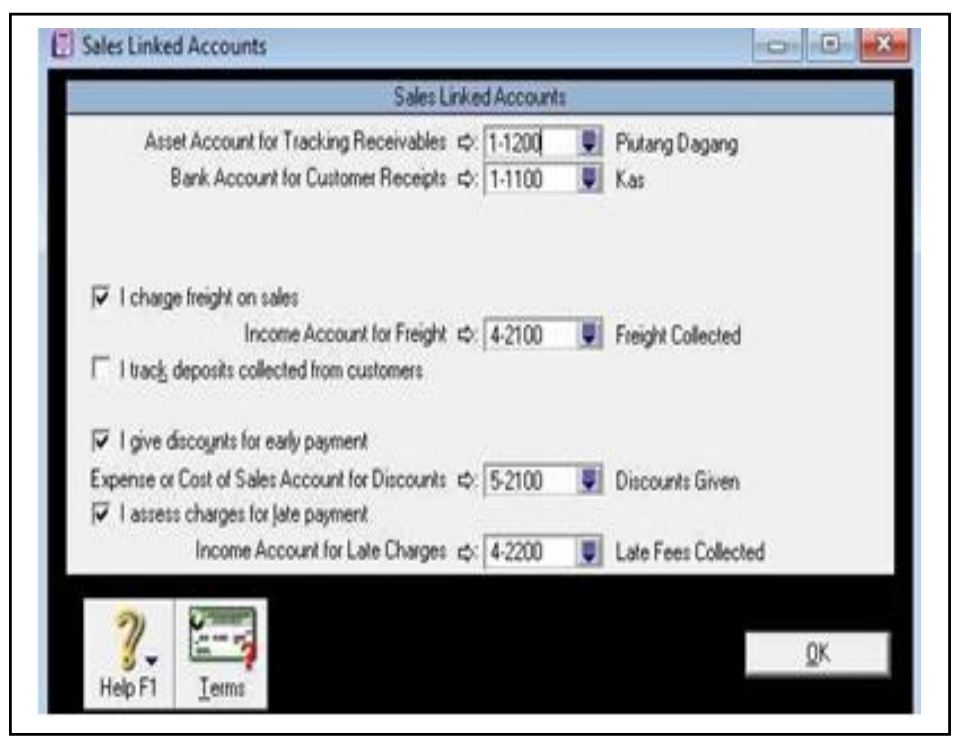

Gambar 4. Sales Accounts

Selanjutnya Link Account untuk Purchases Accounts digunakan untuk mencatat menu pembelian, langkah-langkahnya pilih menu Setup, klik Linked Accounts, klik Purchases Accounts. Isi data seperti gambar di bawah ini Lalu klik $O K$. 


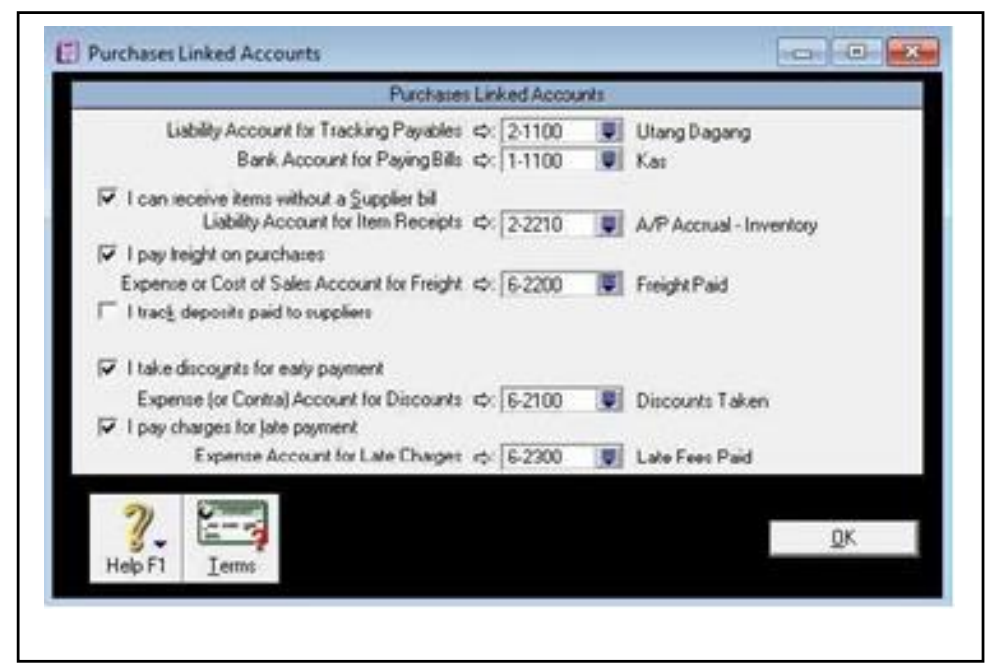

Gambar 5. Purchases Accounts

\section{Pecatatan Transaksi Laporan keuangan CV. One Media Solution dengan aplikasi ABSS}

Langkah berikutnya adalah menginput saldo awal akun dengan cara klik Setup, Balance lalu Accunt Opening Balances. Jika allocated menunjukkan angka Rp.0 maka saldo awal akun yang diinput balance.

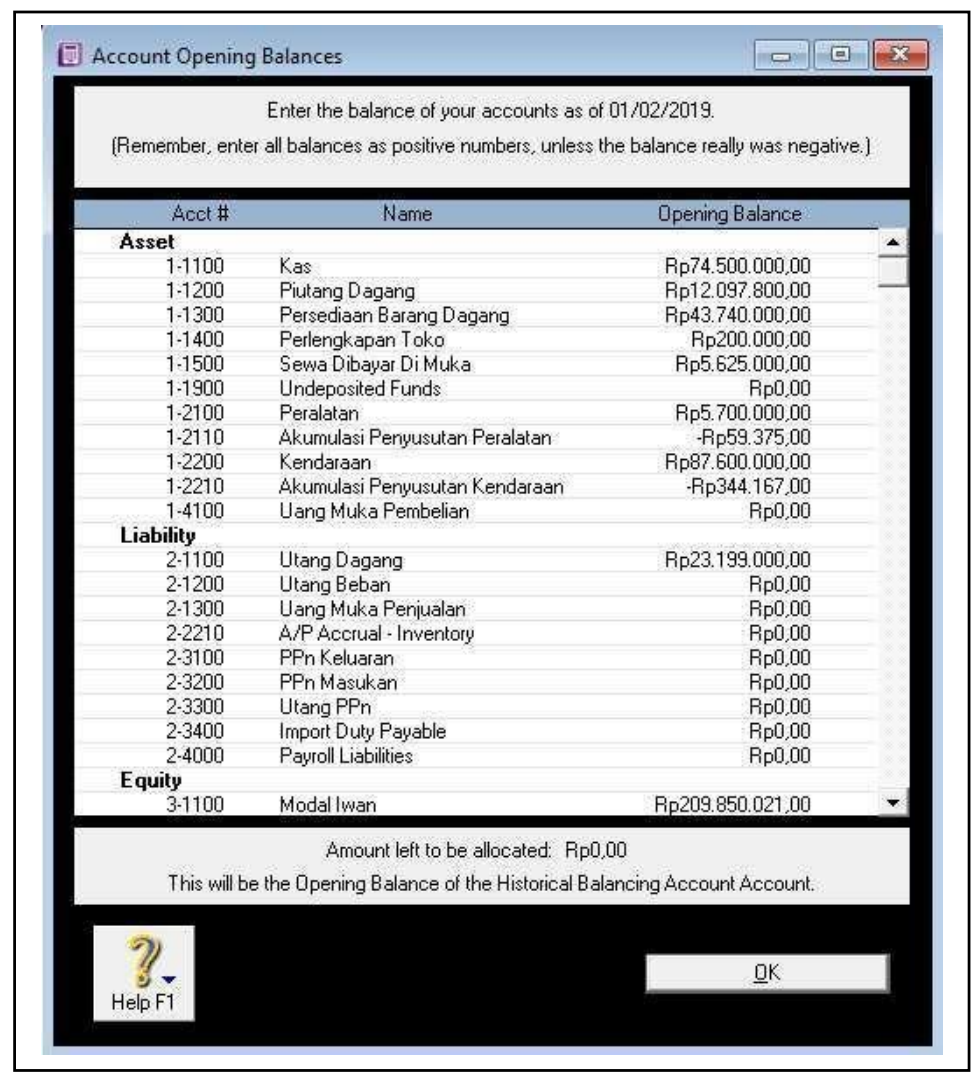

Gambar 6. Tampilan Account Opening Balances

Volume 5 Nomor 2 (2020) Hal. 166-180 
Selain menginput saldo awal akun saldo awal akun, diharuskan untuk menginput saldo awal hutang, dan piutang perusahaan. Langkah untuk menginput saldo awal hutang adalah dengan cara klik setup, Balances lalu Supplier Balances kemudian klik Add Purcases, selanjutnya isi saldo awal hutang usaha, lalu klik record, seperti gambar di bawah ini:

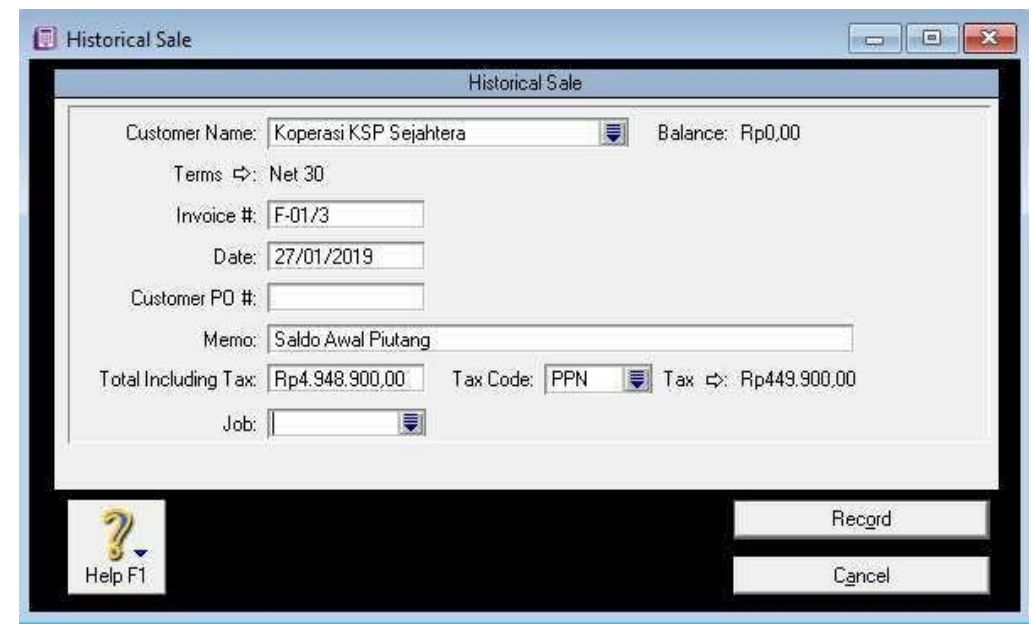

Gambar 7. Add Sales

Setelah penyetingan dan penginputan data selesai, selanjutnya input data transaksi keuangan CV. One Media Solution yang terjadi selama bulan Februari 2019, dikarenakan ada banyaknya transaksi yang dilakukan pada bulan Februari 2019, maka peneliti hanyamenampilkan sample transaksi, di antaranya adalah sebagai berikut:

1. 1 Februari 2019, diterima uang sebesar Rp 800.000 dari Bapak Krisdianto tidak dikenakan PPn, atas penjualan tunai 1 paket Parabola Matrik Mini RR seharga Rp 650.000., tarif pemasangan sebesar Rp 150.000. Untuk mengentri transaksi tersebut berada di fitur Sales, bagian Enter Sales, Pencatatan sesuai gambar 8:

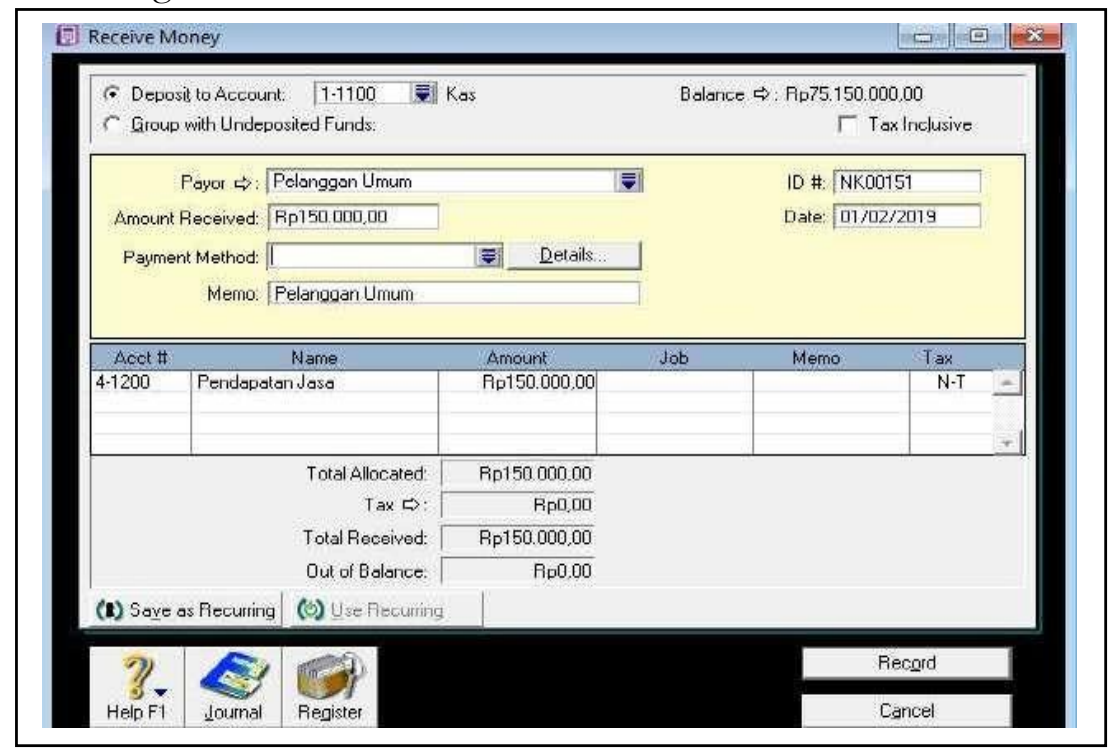

Gambar 8. Transaksi 1 - Receive Money 
2. 7 Februari 2019. diterima uang pelunasan dari SMP N 4 Tegal atas transaksi tertanggal 4 Januari 2019 sebesar Rp 3.675.000 dan tarif pemasangan cctv sebesar Rp.249.000. Untuk mengentri transaksi pelunasan piutang berada di fitur Sales, bagian Receive Payment.

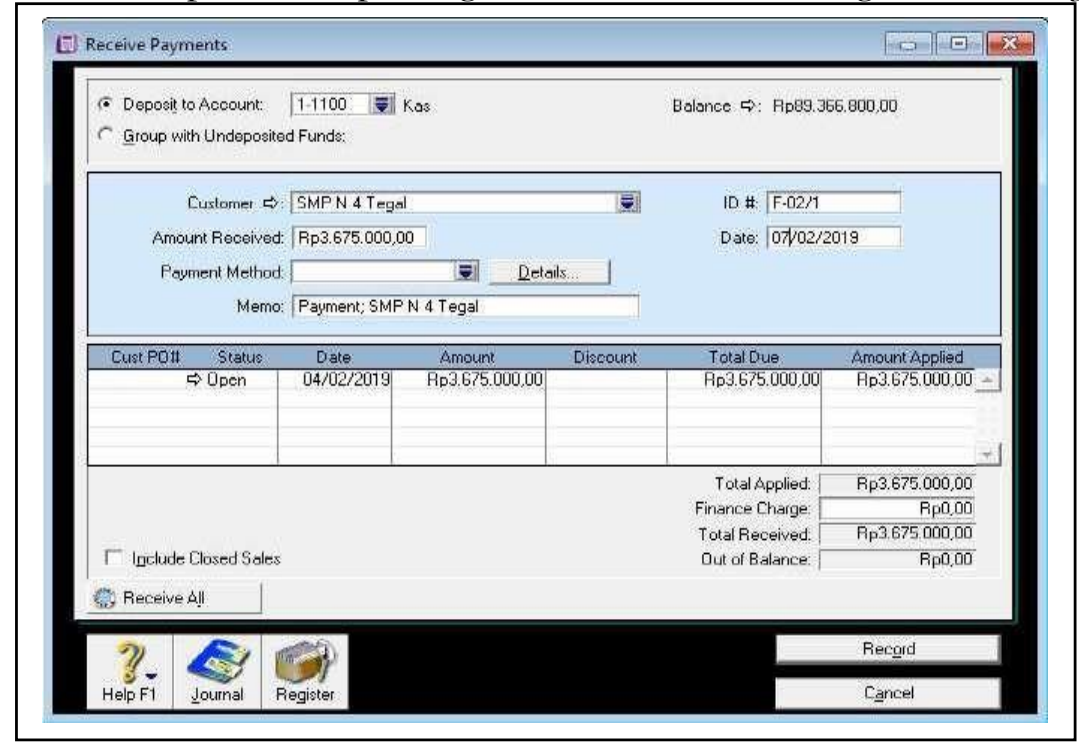

Gambar 9. Transaksi 2 - Receive Payment

3. 9 Februari 2019, dikeluarkan uang untuk pelunasan utang UD Top Zone ElRp.23.199.000 atas transaksi 26 Januari 2019. Untuk mengentri transaksi tersebut berada di fitur Purchases, bagian Pay Bills. Pencatatan sesuai gambar di bawah:

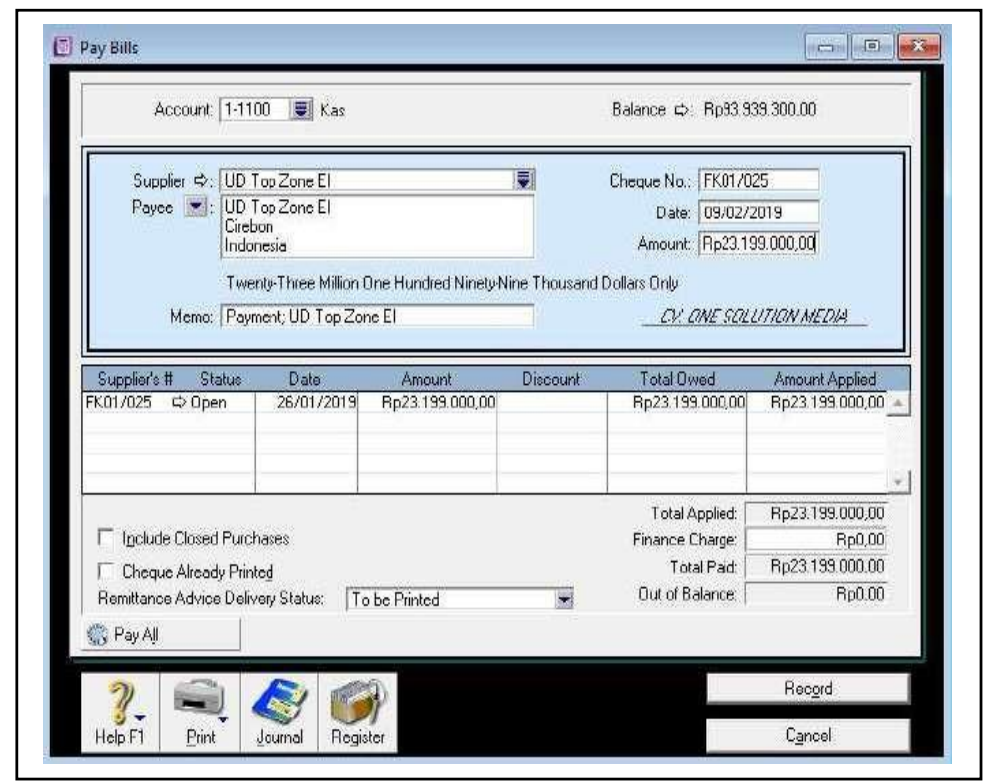

Gambar 10. Transaksi 3 - Pay Bills

4. 18 Februari 2019, diterima uang sebesar Rp 820.000 dari Bapak Dwiki A tidak dikenakan PPn atas penjualan tunai 1 paket Parabola Tanaka Mini RR seharga Rp.670.000, tarif pemasangan Rp.150.000. Untuk mengentri transaksi tersebut berada di fitur Sales, bagian Enter Sales, Pencatatan seperti gambar di bawah ini: 


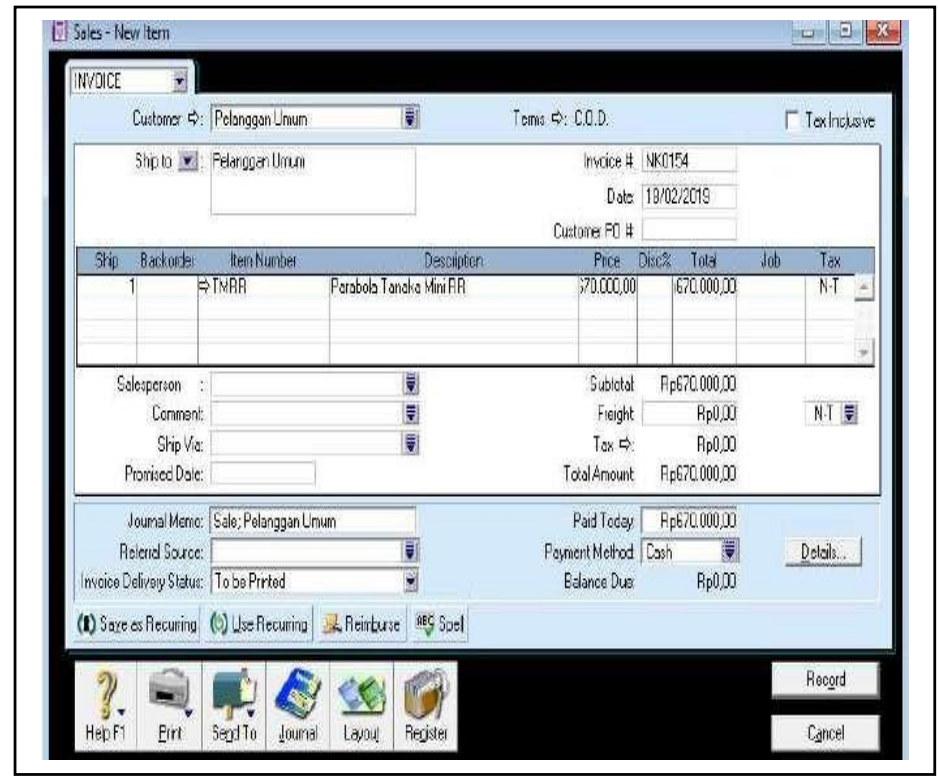

Gambar 11. Transaksi 4 - Sales New Item

\section{Hasil Laporan Menggunakan Aplikasi ABSS}

Laporan yang dihasilkan oleh ABSS Accounting V25 atas input transaksi yang telah di lakukan:

\section{Laporan Laba Rugi}

Laporan Laba Rugi yang dihasilkan oleh ABSS Accounting V25 tampak seperti gambar 17. Income Statement.

\begin{tabular}{|c|c|}
\hline \multirow{2}{*}{\multicolumn{2}{|c|}{$\begin{array}{c}\text { CV. ONE SOLUTION MEDIA } \\
\text { Company No. } \\
\text { JI. Teuku Umar No. 99 Debong Tengah, } \\
\text { Tegal Selatan, Kota Tegal, Jawa Tengah 52133, Indonesia. } \\
\text { Income Statement } \\
\text { January } 2019 \text { through February } 2019\end{array}$}} \\
\hline & \\
\hline \multicolumn{2}{|l|}{ Income } \\
\hline $\begin{array}{l}\text { Penjualan } \\
\text { Pendapatan Jasa } \\
\text { Total Income }\end{array}$ & $\begin{array}{l}\operatorname{Rp} 28.060 .000,00 \\
\operatorname{Rp} 3.563 .000,00 \\
\operatorname{Rp} 31.623 .000,00 \\
\end{array}$ \\
\hline $\begin{array}{l}\text { Cost Of Sales } \\
\text { Harga Pokok Penjualan } \\
\text { Total Cost Of Sales }\end{array}$ & $\begin{array}{l}\text { Rp21.265.000,00 } \\
\text { Rp21.265.000,00 }\end{array}$ \\
\hline Gross Profit & Rp $10.358 .000,00$ \\
\hline $\begin{array}{l}\text { Expenses } \\
\text { Beban Iklan } \\
\text { Beban Telpon \& Listrik } \\
\text { Beban Perlengkapan Toko } \\
\text { Beban Depresiasi } \\
\text { Beban Sewa } \\
\text { Wages \& Salaries } \\
\text { Total Expenses }\end{array}$ & $\begin{array}{r}\text { Rp281.000,00 } \\
\text { Rp885.984,00 } \\
\text { Rp75.000,00 } \\
\text { Rp807.084,00 } \\
\text { Rp1.250.000,00 } \\
\text { Rp4.300.000,00 } \\
\text { Rp7.599.068,00 }\end{array}$ \\
\hline Operating Profit & Rp2.758.932,00 \\
\hline \multicolumn{2}{|l|}{ Other Income } \\
\hline Net Profit/(Loss) & Rp2.758.932,00 \\
\hline
\end{tabular}

Gambar 12. Income Statement

Volume 5 Nomor 2 (2020) Hal. 166-180 


\section{Laporan Perubahan Modal}

Laporan Perubahan Modal dalam ABSS Accounting V25 tidak disediakan terpisah seperti laporan yang lainnya, melainkan dalam Laporan Neraca terdapat rincian mengenai penambahan dan pengurangan modal. Sehingga secara tidak langsung di dalam laporan Neraca tersaji pula laporan Perubahan Modal.

\section{Laporan Neraca}

Laporan Neraca yang dihasilkan oleh ABSS Accounting V25 tampak seperti gambar 18. Balance Sheet.

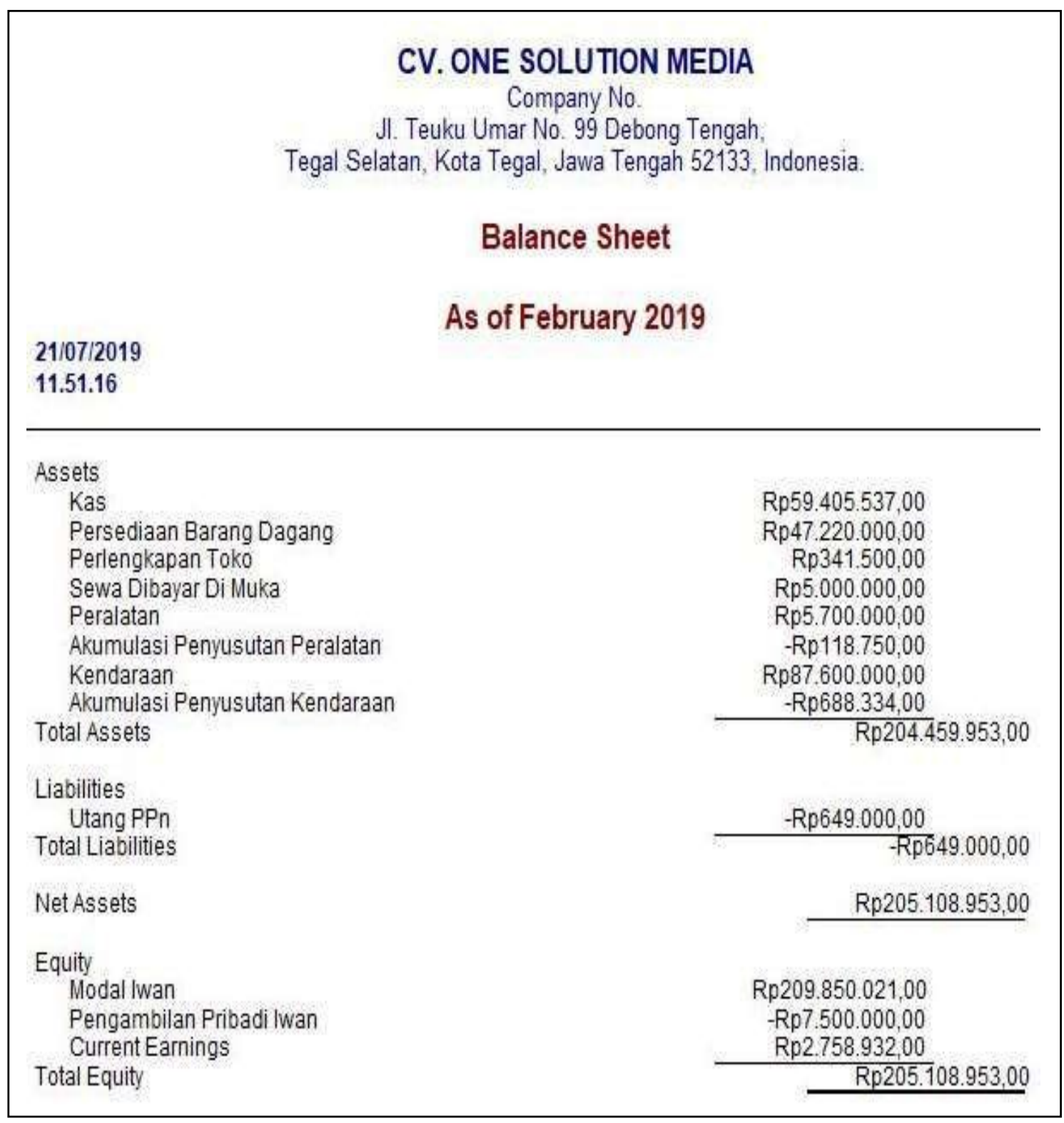

Gambar 13. Balance Sheet 


\section{Pembahasan}

Dalam menganalisa laporan keuangan yang merupakan hasil dari pengelolaan bukti transaksi, maka di temukan kesamaan hasil antara pencatatan manual dengan menggunakan aplikasi ABSS namun perbedaan terletak pada prosesnya.

Untuk lebih jelasnya, berikut perbandingan mengenai proses pembuatan laporan keuangan secara manual maupun dengan aplikasi:

1. Pembuatan laporan menggunakan ABSS Accounting lebih cepat dibandingkan dengan manual, karena tidak diperlukannya pembuatan tabel untuk mencatat data, pengelolaan laporan keuangan akan lebih cepat juga dikarenakan sistem posting yangotomatis dan penyususnan laporan otomatis. Pengguna hanya perlu memasukan data dalam bukti transaksi yang tersedia, setelah itu sistem akan langsung memproses data dan informasi dapat segera diperoleh. Hal ini juga terbukti seperti penelitian terdahulunya yang dilakukan oleh Rudi yang mengatakan bahwa aplikasi ABSS Accounting dapat mempercepat pembuatan laporan [12].

2. Laporan bisa langsung ditampilkan setelah transaksi jurnal khusus dan jurnal penyesuaiaan selesai di input. Berbeda dengan pencatatan manual yang memerlukan pembuatan buku besar, neraca saldo, dan neraca lajur untuk memudahkan pembuatan laporan.

3. Laporan dibuat secara otomatis sehingga tidak perlu menyusun maupun menghitung secara manual dengan alat bantu seperti kalkulator.

4. Resiko mengalami kesalahan pencatatan lebih kecil dibandingkan dengan pembuatan laporan keuangan secara manual

\section{Penutup}

Penerapan aplikasi ABSS Accounting untuk pencatatan transaksi keuangan CV. One Solution Media menjadikan proses pencatatan data lebih mudah, perusahaan juga lebih mudah dalam mengambil keputusan karena pada proses pencatatan aplikasi sudah sesuai dengan standar akuntansi perusahaan. Penggunaan aplikasi mampu menghasilkan laporan keuangan dengan cepat, karena setelah data diinput dalam jurnal, laporan bisa langsung ditampilkan. Sedangkan, pembuatan laporan secara manual memerlukan buku besar, neraca saldo dan neraca lajur dalam membuat laporan sehingga memakan waktu cukup lama. Laporan Neraca (Balance Sheet) yang dihasilkan leh ABSS Accounting tidak terpisah dari laporan Perubahan Modal. Hal ini mampu memudahkan pembaca dalam menganalisa laporan tersebut. Kekurangan yang masih dijumpai dalam penelitian ini adalah belum terdapat pelaporan fitur pajak, sehingga saat perusahaan akan melaporkan pajak melakukan penghitungan secara terpisah. Kekurangan selanjutnya adalah belum tersedia fitur multi gudang, sehingga penginputan data beberpa gudang CV One Solution Media tidak bisa dijadikan satu. Peneliti berharap penerapan ABSS Accounting untuk mengelola transaksi keuangan meningkatkan pengawasan terhadap transaksi keuangan pada perusahaan, agar bukti-bukti transaksi lengkap tidak ada yang hilang.

\section{Daftar Pustaka}

[1] Ansari, D. Lockwood, J. Nino, E. Thies, and B. Modarress, "Application of Six-Sigma in finance : a case study," J. Case Res. Bus. Econ., 2018.

[2] H. R. Yuliantoro, "Penyusunan Laporan Keuangan Menggunakan MYOB Accounting Versi 18 Pada Toko Sepatu Heri," J. Akunt. Keuang. Dan Bisnis, 2015.

[3] A. R. Fachrizal, Muhammad Rachmanto, "Perancangan Enterprise Architecture dengan Framework TOGAF ADM Pada Rumah Sakit Umum di Cimahi," J. Teknol. dan Inf., 2018, doi: 10.34010/jati.v8i2.1037.

[4] Normah, "Implementasi It Pada Sistem Informasi Akuntansi Pt. Master Grafika Jakarta," 
Tek. Komput., 2018.

[5] R. Selamet and V. Apriana, "Penerapan Aplikasi Myob Untuk Pengolahan Data Akuntansi Studi Kasus : Py.Quantum Electrindo Lestari," J. Chem. Inf. Model., 2019.

[6] S. A. Rahmat Hidayat Lubis, "PENGANTAR AKUNTANSI JASA BERBASIS SAK IFRS DAN SAK ETAP," in GAMBARAN UMUM AKUNTANSI, 2017.

[7] Mulyadi, "Pengertian sistem akuntansi," Fak. Yogyakarta, 2016.

[8] S. K. Tata Sutabri, "Sistem Informasi Manajemen (edisi revisi)," CV. ANDI OFFSET, 2016.

[9] M. B. Romney and P. J. Steinbart, "Pengertian sistem menurut Marshall B Romney dan Paul John Steinbart," in Sistem Informasi Akuntansi, 2015.

[10] Zaenuri, "PENERAPAN APLIKASI SOFTWARE MYOB PADA PERUSAHAAN DAGANG ( TOKO ANGKASA KOMPUTER ) Mochamad Zaenuri," J. AMIK JTC Semarang, 2013.

[11] Kardiyem, I. Anisyukurillah, and P. N. Sari, "Profesionalisme Guru Mgmp Akuntansi Smk Kota Semarang Melalui Transformasi," J. PANJAR, 2019.

[12] S. B. Kristanto and C. Windyan, "Persepsi Kualitas dan Performa Sistem Aplikasi Akuntansi MYOB pada Pengguna Level Dasar," J. Keuang. dan Perbank., 2018.

[13] Sugiyono, "Metode Penelitian Bisnis (Pendekatan Kuantitatif, Kualitatif, Kombinasi dan R\&D)," in Metodelogi Penelitian, 2017.

[14] N. Indriantoro and B. Supomo, "Metode Penelitian Bisnis untuk Akuntansi \& Manajemen," in EKONOMI, 2016.

[15] E. Suyanti, "Pengolahan Laporan Keuangan Menggunakan MYOB Accounting V," Repos. BSI, 2017. 